\section{Combined Heating Applications Increased Plant Production from Bedded Sweetpotato Roots}

\author{
Melvin R. Hall ${ }^{1}$ \\ Department of Horticulture, University of Georgia Coastal Plain Experiment \\ Station, Tifton, GA 31793
}

Additional index words. Ipomoea batatas, extended curing, presprouting, midstorage heating, emergence

\begin{abstract}
Red Jewel' sweetpotato [Ipomoea batatas (L.) Lam.] roots were cured [32 $\pm 1 \mathrm{C}$, $85 \%$ relative humidity $(\mathrm{RH})]$ for 7 days immediately after harvest and then subjected to selected single or combined applications of additional curing, midstorage heating, and presprouting not to exceed 21 days. Extended curing was applied for 0, 7, 14, or 21 additional days before storage $(16 \pm 1 \mathrm{C}, 85 \% \mathrm{RH})$. Midway through storage, roots were heated $(32 \pm 1 \mathrm{C}, 85 \% \mathrm{RH})$ for $0,7,14$, or 21 days and placed back into storage. Before being bedded, roots were presprouted $(32 \pm 1 \mathrm{C}, 85 \% \mathrm{RH})$ for $0,7,14$, or 21 days. Roots that received extended curing, midstorage heating, or presprouting or a combination of these treatments emerged earlier and produced more cumulative early, midseason, and total plants than nonheated roots. Roots heated once for 21 days produced more plants than roots heated once for 14 days; those heated for 21 days in a combination of short durations produced more early, midseason, and total number of plants than roots heated once for 21 days.
\end{abstract}

Presprouting $(32 \pm 1 \mathrm{C}, 85 \%$ relative humidity $(\mathrm{RH})]$ sweetpotato roots for 3 weeks immediately before bedding has been a standard method for increasing plant production for $>30$ years (Deonier and Kushman, 1960). Immediately after harvest, sweetpotato roots should be cured $(32 \pm 1 \mathrm{C}, 85 \% \mathrm{RH})$ for $\approx 1$ week to heal wounds, and then they should be stored $(16 \pm 1 \mathrm{C}, 85 \% \mathrm{RH})$ to maintain quality (Steinbauer and Kushman, 1971). Curing and presprouting conditions are identical. Extending the curing period by 11 days increased plant production (Deonier and Kushman, 1960) but was not as effective as presprouting immediately before bedding. Extended curing has not been adopted commercially, partly because of excess sprouting, shrinkage, and shortened storage life in facilities lacking refrigeration (Steinbauer and Kushman, 1971). However, these problems occurred at a much lower frequency under controlled storage conditions, and extending the curing period for up to 12 days successfully accelerated plant emergence and increased early and total plant production (Hall, 1992).

Rising energy costs have caused some growers to restrict the use of presprouting.

Received for publication 29 Oct. 1993. Accepted for publication 31 Mar. 1994. Mention of a trademark, proprietary product, or vendor does not imply endorsement by the Georgia Agricultural Experiment Station, nor criticism of similar products not mentioned. This research was supported by state and Hatch Act funds allocated to the Georgia Agricultural Experiment Stations. The cost of publishing this paper was defrayed in part by the payment of page charges. Under postal regulations, this paper therefore must be hereby marked advertisement solely to indicate this fact.

${ }^{1}$ Associate Professor. midstorage heating, and presprouting days at $32 \mathrm{C}$. bedding with an equivalent single duration of heat applied at one of these times. In this study, heat was applied for $0,7,14$, or 21 days as extended curing, midstorage heating, or presprouting or in combinations of these durations and times.

\section{Materials and Methods}

'Red Jewel' sweetpotatoes were harvested on 19 Nov. 1987 . Roots 4 to $6 \mathrm{~cm}$ in diameter and 8 to $10 \mathrm{~cm}$ long were randomly assigned to lots of 10 for imposing selected heat treatments. Each lot was cured for 7 days and then cured for an additional $0,7,14$, or 21 days. These roots were a mixture of large canner (2.5-5.0 $\mathrm{cm}$ in diameter, $5.0-18.0 \mathrm{~cm}$ long) and small U.S.\#1 (>5.0-18.0 cm in diameter, $7.5-23.0 \mathrm{~cm}$ long) grades and were considered ideal size for commercial sweetpotato plant production. Roots from each of the curing treatments were placed into midstorage heating $(32 \pm 1 \mathrm{C}, 85 \% \mathrm{RH})$ on 27 or 30 Dec. 1987 or on 3 Jan. 1988 for 21, 14, and 7 days, respectively, and then returned to normal storage $(16 \pm 1 \mathrm{C}, 85 \% \mathrm{RH})$. Roots not subjected to midstorage heating remained in normal storage. All roots were presprouted for $0,7,14$, or 21 days immediately before bedding on 18 Feb. 1988. Space did not accommodate all treatments of a complete factorial arrangement. Also, because the standard presprouting duration is $\approx 21$ days (Deonier and Kushman, 1960 ), only the 20 treatments with single or combined durations $\leq 21$ days were included in this test. After presprouting, roots were immersed for $15 \mathrm{sec}$ in $640 \mathrm{~g}$ of $75 \%$ wettable powder of 2,6-dichloro-4-nitroaniline (dicloran) in 40 liters of water. Roots were airdried and then placed in $30 \times 40-\mathrm{cm}$ contiguous plots in a ground bed in a greenhouse and covered with $5 \mathrm{~cm}$ of fumigated Tifton loamy

Table 1. Number of days from bedding until emergence and cumulative early, midseason, and total plant production in plots of 10 bedded sweetpotato roots as influenced by combinations of extended curing,

\begin{tabular}{|c|c|c|c|c|c|c|c|}
\hline \multirow{3}{*}{$\begin{array}{l}\text { Treat- } \\
\text { ment } \\
\text { no. }\end{array}$} & \multicolumn{3}{|c|}{ No. days of treatment at $32 \mathrm{C}$} & \multirow{3}{*}{$\begin{array}{c}\text { Emergence } \\
\text { (days } \\
\text { from } \\
\text { bedding) }\end{array}$} & \multirow{2}{*}{\multicolumn{3}{|c|}{ Cumulative no. plants }} \\
\hline & \multirow[b]{2}{*}{$\begin{array}{l}\text { Extended } \\
\text { curing }\end{array}$} & \multirow{2}{*}{$\begin{array}{c}\text { Mid- } \\
\text { storage } \\
\text { heating }\end{array}$} & \multirow{2}{*}{$\begin{array}{c}\text { Pre- } \\
\text { sprout- } \\
\text { ing }\end{array}$} & & & & \\
\hline & & & & & Early & $\begin{array}{c}\text { Mid- } \\
\text { season }\end{array}$ & Total \\
\hline$\overline{1}$ & 0 & 0 & 0 & $26^{z}$ & 6 & 36 & 50 \\
\hline 2 & 0 & 0 & 7 & 16 & 45 & 65 & 88 \\
\hline 3 & 0 & 7 & 0 & 19 & 39 & 61 & 83 \\
\hline 4 & 7 & 0 & 0 & 17 & 40 & 62 & 80 \\
\hline 5 & 0 & 0 & 14 & 16 & 47 & 70 & 94 \\
\hline 6 & 0 & 14 & 0 & 17 & 37 & 60 & 80 \\
\hline 7 & 14 & 0 & 0 & 11 & 41 & 72 & 88 \\
\hline 8 & 0 & 7 & 7 & 15 & 45 & 64 & 83 \\
\hline 9 & 7 & 0 & 7 & 14 & 40 & 60 & 80 \\
\hline 10 & 7 & 7 & 0 & 15 & 41 & 61 & 77 \\
\hline 11 & 0 & 0 & 21 & 14 & 48 & 68 & 86 \\
\hline 12 & 0 & 21 & 0 & 14 & 41 & 59 & 84 \\
\hline 13 & 21 & 0 & 0 & 12 & 37 & 56 & 80 \\
\hline 14 & 0 & 7 & 14 & 12 & 45 & 74 & 93 \\
\hline 15 & 7 & 0 & 14 & 12 & 50 & 70 & 92 \\
\hline 16 & 7 & 14 & 0 & 9 & 48 & 72 & 93 \\
\hline 17 & 0 & 14 & 7 & 14 & 47 & 68 & 87 \\
\hline 18 & 14 & 0 & 7 & 13 & 56 & 74 & 99 \\
\hline 19 & 14 & 7 & 0 & 13 & 49 & 70 & 89 \\
\hline 20 & 7 & 7 & 7 & 14 & 46 & 74 & 92 \\
\hline $\mathrm{F}$ test & & & & $* *$ & $* *$ & $* *$ & $* *$ \\
\hline
\end{tabular}


of midstorage heating or presprouting (contrast 9). With combined applications of 21 days of heating, average emergence was earlier when the last application of heat was for 14 days of presprouting or midstorage heating (11 vs. $14, P \leq 0.05)$ (contrast 14 ).

Significant $\mathrm{F}$ tests indicate differences in treatment means for cumulative number of early, midseason, and total plant count (Table 1). Orthogonal contrasts 1 and 11 were significant for cumulative early, midstorage, and total plant count, while contrast 3 was significant for total number of plants. Nonheated control roots produced only $14 \%$ as many cumulative early plants as the average produced by heated roots, and the percentage of midseason and total cumulative plants from nonheated roots increased, but was still $<60 \%$ of the average produced under all heat treatments (Table 2). These findings are consistent with expectations of increased plant production from heating treatments (Deonier and Kushman 1960; Hall, 1987, 1990, 1992, 1993).

Lack of significance of contrast 2 (Table 1) indicates that average plant production from single application of 14 or 21 days of heat did not differ from 7 days of heating. This finding differs from previous ones (Hall, 1987, 1992, 1993) that showed an increase in the number of plants produced from bedded sweetpotato roots with increasing durations of heat treatments. However, production of more plants in total from 21 days compared to 14 days of heat in a single duration (contrast 3) (Table 2) supports the previous findings and suggests that the confounding influence of timing and duration of heat treatments for the average of 14- and 21-day heat treatments could account for the lack of significance in contrast 2 .

The average cumulative early, midseason, and total plant production was greater from 21 days of heat applied in combinations, including extended curing, midstorage heating, and presprouting, than from a single 21-day application of heat applied at any one of these times (Table 2). Lack of significance of contrasts 12 and 13 (Table 1) indicates that timing of the 21-day single applications of heat did not influence plant production. Also, lack of sigsurface were harvested from individual plots once each week for 9 weeks. Data presented include the number of days from bedding until first plant emergence and the cumulative number of plants harvested during the first 3 weeks (early plants), 6 weeks (midseason plants), and 9 weeks (total plant count). After the ninth plant harvest, bedded roots were removed and evaluated for severity of deterioration, but their good condition precluded analysis. Data were subjected to a $(\mathrm{x}+0.5)^{1 / 2}$ transformation for analyses, and transformed means were back-transformed for presentation. The experimental design was a randomized complete block with three replications. Data were tested by analysis of variance using preplanned orthogonal comparisons.

\section{Results and Discussion}

Significant contrast 1 (Table 1) indicates that plants emerged earlier from heated than nonheated control roots (14 vs. 26 days, $P \leq$
0.01). This observation is consistent with other for 7 days emerged later than the average of days ( 17 vs. 12 days, $P \leq 0.01$ ) (cont which is consistent with previous results showing earlier emergence with increasing duration of heating (Hall, 1987, 1992, 1993). Roots receiving heat for 14 days in a single application emerged earlier ( 10 vs. $13, P \leq 0.01)$ than roots heated for 21 days in a single application (contrast 3 ). Roots receiving 14 days extended curing emerged earlier (11 vs. $17, P \leq 0.01$ ) than the average from roots receiving 14 days
Table 2. Mean cumulative early, midseason, and total plant production in plots of 10 bedded sweetpotato roots as influenced by combinations of extended curing, midstorage heating, and presprouting days at $32 \mathrm{C}$.

\begin{tabular}{llccc}
\hline \hline Contrast & & \multicolumn{3}{c}{ Cumulative no. plants } \\
\cline { 3 - 5 } no. & \multicolumn{1}{c}{ Description $^{2}$} & Early & Midseason & Total \\
\hline 1 & Nonheated control (1) & 44 & 36 & 49 \\
& Heated $(2-20)$ & $6^{\mathrm{y}}$ & 66 & 87 \\
& & 42 & $6 *$ & $* *$ \\
3 & 14 days $(5,6,7)$ & 47 & 68 & 89 \\
& 21 days $(11,12,13)$ & $\mathrm{NS}$ & $\mathrm{NS}$ & $*$ \\
11 & $21 \mathrm{E}(11) ; 21 \mathrm{M}(12) ; 21 \mathrm{P}(13) ;$ & 42 & 61 & 83 \\
& $7 \mathrm{M}+14 \mathrm{P}(14) ; 14 \mathrm{M}+7 \mathrm{P}(17) ;$ & & & \\
& $7 \mathrm{E}+14 \mathrm{P}(15) ; 7 \mathrm{E}+7 \mathrm{M}+7 \mathrm{P}(20) ;$ & 49 & 72 & 92 \\
& $7 \mathrm{E}+14 \mathrm{M}(16)$ & $*$ & $* *$ & $* *$
\end{tabular}

${ }^{ } \mathrm{E}=$ extended curing; $\mathrm{M}=$ midstorage heating; $\mathrm{P}=$ presprouting. Alphanumeric code denotes the number of days and times that roots were heated, e.g., $7 \mathrm{E}+7 \mathrm{M}=7$ days of extended curing plus 7 days midstorage heating. Treatment numbers appear in parentheses.

${ }^{y}$ Analyses conducted on transformed data; back-transformed means are presented.

ss, *,**Nonsignificant or significant at $P \leq 0.05$ or 0.01 , respectively. 
nificance of contrasts 14-19 indicates that the various combinations of extended curing, midstorage heating, and presprouting for 21 days of heating were similar in their influence on plant production. These findings support earlier ones showing a complementary effect of enhancing plant production from short durations of heating applied in combination as extended curing and presprouting (Hall, 1992) or extended curing, midstorage heating, and presprouting (Hall, 1993). However, the enhanced plant production demonstrated here from combinations of short durations of heating, as compared with a single application of the same number of days, has not been reported previously. Application of short dura- tions of heating in combination as extended curing, midstorage heating, or presprouting has not been adopted commercially. Such adjustments in timing and duration of heat treatments, however, could be beneficial for reducing energy costs, as pointed out previously (Hall, 1992, 1993), and for further reducing plant production costs by maximizing the number of plants produced from bedded sweetpotato roots.

\section{Literature Cited}

Deonier, M.T. and L.J. Kushman. 1960. The effect of presprouting and type of bed on the early production of sweet potato plants. Proc. Amer. Soc. Hort. Sci. 75:557-560.
Hall, M.R. 1987. Short duration presprouting enhances sweet potato plant production. HortScience 22:314.

Hall, M.R. 1990. Short duration presprouting, ethephon, and cutting increase plant production by sweetpotato roots. HortScience 25:403-404.

Hall, M.R. 1992. Brief extensions of curing and presprouting increased plant production from bedded sweetpotato roots. HortScience 27:1080 1082.

Hall, M.R. 1993. Midstorage heating increased plant production from bedded sweetpotato roots. HortScience 28:780-781.

Steinbauer, C.E. and L.J. Kushman. 1971. Curing and storage, p. 42-46. In: C.E. Steinbauer and L.J. Kushman (eds.). Sweetpotato culture and diseases. Agr. Hdbk. 388. Agr. Res. Serv., U.S. Dept. Agr., Washington, D.C. 